\title{
POROUS GELATIN HYDROGELS BASED ON CLAY PROMOTED BY CALCIUM MINERALIZATION
}

\section{HIDROGELURI POROASE DE GELATINĂ PE BAZĂ DE ARGILĂ ACTIVATĂ PRIN MINERALIZARE CU CALCIU}

\author{
Tao ZHANG ${ }^{1,2}$, Ying GONG ${ }^{1,3}$, Xiaoling LIU $^{1}$, Bo TENG ${ }^{1}$, Wuyong CHEN $^{1 *}$ \\ ${ }^{1}$ National Engineering Laboratory for Clean Technology of Leather Manufacture, Sichuan University, Chengdu, Sichuan, 610065, China, email: \\ wuyong.chen@163.com \\ ${ }^{2}$ Department of Chemie, Technische Universität Dresden, Dresden, 01069, Germany, email: Tao.Zhang@mailbox.tu-dresden.de \\ ${ }^{3}$ College of Chemistry and Chemical Engineering, Yunnan Normal University, 650500, Kunming, China, email: gongying_2004@163.com
}

\section{POROUS GELATIN HYDROGELS BASED ON CLAY PROMOTED BY CALCIUM MINERALIZATION}

ABSTRACT. A bioclean method was proposed to prepare porous gelatin-based hydrogels using clay as porogen, water as solvent and calcium as promoter: firstly, laponite clay and gelatin were individually dissolved in deionized water to get aqueous solutions; then the two solutions were blended and exposed to $-20^{\circ} \mathrm{C}$ for $24 \mathrm{~h}$ to form physically crosslinked hydrogel; finally the hydrogel was soaked in a calcium chloride solution at room temperature for $48 \mathrm{~h}$ to obtain matrixes with welldefined voids. The gelatin molecules intercalated into the clay slices gaining uniform composites, which were confirmed by atomic force microscopy, infrared spectrum, X-ray diffraction and differential scanning calorimetry analyses. As proved by scanning electron microscopy study, in the matrix containing $5 \%$ gelatin and $2 \%$ clay, the voids were interconnecting, and the size of pores focused on a range of 100-200 im. Such matrix might serve as scaffolds for tissue engineering because of its typical pore structure and size distribution. Additionally, such material could be used as wound dressings, for it was able to provide a fine moist environment for a surface.

KEY WORDS: hydrogel, gelatin, clay.

\section{HIDROGELURI POROASE DE GELATINĂ PE BAZĂ DE ARGILĂ ACTIVATĂ PRIN MINERALIZARE CU CALCIU}

REZUMAT. S-a propus o metodă curată de preparare a hidrogelurilor poroase pe bază de gelatină utilizând argilă ca agent porogen, apă ca solvent şi calciu ca activator: mai întâi, s-au dizolvat separat laponita (argilă) şi gelatina în apă deionizată pentru a obţine soluţii apoase; apoi s-au amestecat cele două soluţii şi au fost expuse la $-20^{\circ} \mathrm{C}$ timp de $24 \mathrm{~h}$, pentru a forma un hidrogel reticulat fizic; în cele din urmă hidrogelul a fost înmuiat într-o soluţie de clorură de calciu la temperatura camerei, timp de $48 \mathrm{~h}$, pentru a obţine matrice cu pori bine definiţi. Moleculele de gelatină s-au intercalat între discurile de argilă, alcătuind compozite uniforme, fapt confirmat prin microscopie de forţă atomică, spectroscopie în infraroşu, difracţie de raze X şi calorimetrie diferenţială de baleiaj. După cum s-a dovedit prin studiul de microscopie electronică de baleiaj, în matricea care conţine $5 \%$ gelatină şi $2 \%$ argilă, porii s-au interconectat, iar dimensiunile porilor s-au concentrat în intervalul 100-200 ěm. O asemenea matrice ar putea servi ca suport pentru ingineria ţesuturilor datorită structurii sale poroase şi distribuţiei dimensiunilor porilor. În plus, un astfel de material ar putea fi folosit ca pansament, întrucât este în măsură să ofere un mediu fin şi umed pentru o altă suprafaţă.

CUVINTE CHEIE: hidrogel, gelatină, argilă.

\section{DES HYDROGELS POREUX DE GÉLATINE À BASE D'ARGILE ACTIVÉE PAR LA MINÉRALISATION À L'AIDE DE CALCIUM}

RÉSUMÉ. On a proposé une méthode bio de préparer des hydrogels poreux à base de gélatine en utilisant de l'argile comme agent porogène, de l'eau comme solvant et du calcium comme activeur: tout d'abord, l'argile laponite et la gélatine ont été individuellement dissoues dans de l'eau déminéralisée pour obtenir des solutions aqueuses; ensuite les deux solutions ont été mélangées et exposées à $-20^{\circ} \mathrm{C}$ pendant 24 heures pour former un hydrogel réticulé physiquement; enfin l'hydrogel a été trempé dans une solution de chlorure de calcium à la température ambiante pendant 48 heures pour obtenir des matrices à pores bien définis. Les molécules de gélatine sont intercalées dans les tranches d'argile en formant des composites uniformes, qui ont été confirmées par microscopie à force atomique, spectres infrarouge, diffraction de rayons $X$ et calorimétrie différentielle à balayage. Comme le prouve l'étude de microscopie électronique à balayage, dans la matrice contenant $5 \%$ de gélatine et $2 \%$ d'argile, les pores sont interconnectés, et les tailles des pores sont concentrées sur une gamme de 100-200 ìm. Cette matrice peut servir comme substrat pour l'ingénierie tissulaire en raison de sa structure poreuse et la distribution granulométrique. En outre, un tel matériau pourrait être utilisé comme pansement, car il est en mesure de fournir un environnement doux et humide pour une autre surface.

MOTS CLÉS: hydrogel, gélatine, argile.

\footnotetext{
*Correspondence to: Wuyong CHEN, National Engineering Laboratory for Clean Technology of Leather Manufacture, Sichuan University, Chengdu, Sichuan, 610065, China, email: wuyong.chen@163.com
} 


\section{INTRODUCTION}

In recent years, considerable efforts have been put into natural macromolecule based hydrogels, since such materials hold incomparable biocompatibility, biodegradability and bioactivity which are precisely pre-requisite in a biosystem. Furthermore, the controlled porosity, pore size, degradation rate, as well as tissue matching mechanical properties and appropriate biological response obtained from biocompatible and biodegradable materials are essential for tissue engineering [1].

Gelatin, as a kind of natural polypeptide obtained from collagen, consists of 18 different amino acids of various active groups such as amino, carboxyl, hydroxyl and phenolic hydroxyl. These side groups endow gelatin with excellent physical and chemical characteristics such as film-forming, surface activity, reversible sol-gel transformation, polyampholyte, and high reactivity [2]. In this article, two biocompatible materials, gelatin and clay, were proposed to prepare porous hydrogels in an aqueous medium. This technique, avoiding the use of organic solvent, may provide a simple and clean technique to fabricate macroporous scaffolds for tissue engineering applications or other related fields.

\section{MATERIALS AND METHODS}

\section{Materials}

Gelatin (type B, G9382, isoelectric point 4.7-5.2), derived from bovine hide with an alkaline hydrolysis process, was purchased from Sigma (USA). The clay (laponite, W233) with an average diameter of $25 \mathrm{~nm}$ was kindly supplied by Weipu Co. Ltd. (China) and its chemical compositions are $\mathrm{SiO}_{2} 55 \sim 57 \%, \mathrm{MgO} 23.5 \sim 25.0 \%, \mathrm{Na}_{2} \mathrm{O}$ 2.8 3.8\%, $\mathrm{Li}_{2} \mathrm{O} 1.2 \sim 1.5 \%, \mathrm{~F} 5 \sim 5.8 \%$. Calcium chloride and other reagents were analytical grade.

\section{INTRODUCERE}

În ultimii ani, s-au depus eforturi considerabile pentru dezvoltarea hidrogelurilor pe bază de macromolecule naturale, întrucât aceste materiale deţin biocompatibilitate, biodegradabilitate şi bioactivitate incomparabile, care constituie condiţii necesare într-un biosistem. Mai mult, porozitatea controlată, dimensiunea porilor, gradul de degradare, precum şi proprietăţile mecanice comparabile cu cele ale ţesuturilor şi răspunsul biologic adecvat obţinut de la materialele biocompatibile şi biodegradabile sunt esenţiale pentru ingineria tisulară [1].

Gelatina, un tip de polipeptidă naturală obţinută din colagen, are în compoziţia sa 18 aminoacizi cu diferite grupări active precum amino, carboxil, hidroxil şi hidroxil fenolice. Aceste grupări secundare oferă gelatinei proprietăţi fizice şi chimice excelente cum ar fi: capacitatea de a forma pelicule, activitate de suprafaţă, transformare sol-gel reversibilă, caracter poliamfolit şi reactivitate mare [2]. În acest articol s-au propus două materiale biocompatibile, gelatina şi argila, pentru prepararea unor hidrogeluri poroase într-un mediu apos. Neimplicând utilizarea solvenţilor organici, această tehnică poate oferi o modalitate simplă şi curată de a realiza suporturi macroporoase pentru utilizări în ingineria tisulară sau în alte domenii conexe.

\section{MATERIALE ŞI METODE}

\section{Materiale}

Gelatina (tip B, G9382, punct izoelectric 4,7-5,2), obţinută din piele bovină printr-un proces de hidroliză alcalină, a fost achiziţionată de la Sigma (USA). Argila (laponită, W233) cu diametru mediu de $25 \mathrm{~nm}$ a fost furnizată de Weipu Co. Ltd. (China), iar compoziţia chimică a acesteia este $\mathrm{SiO}_{2} 55 \sim 57 \%, \mathrm{MgO} 23,5 \sim 25,0 \%$, $\mathrm{Na}_{2} \mathrm{O} 2,8 \sim 3,8 \%, \mathrm{Li}_{2} \mathrm{O}$ 1,2 1,5\%, F 5 5,8\%. Clorura de calciu şi ceilalţi reactivi au fost de calitate analitică. 


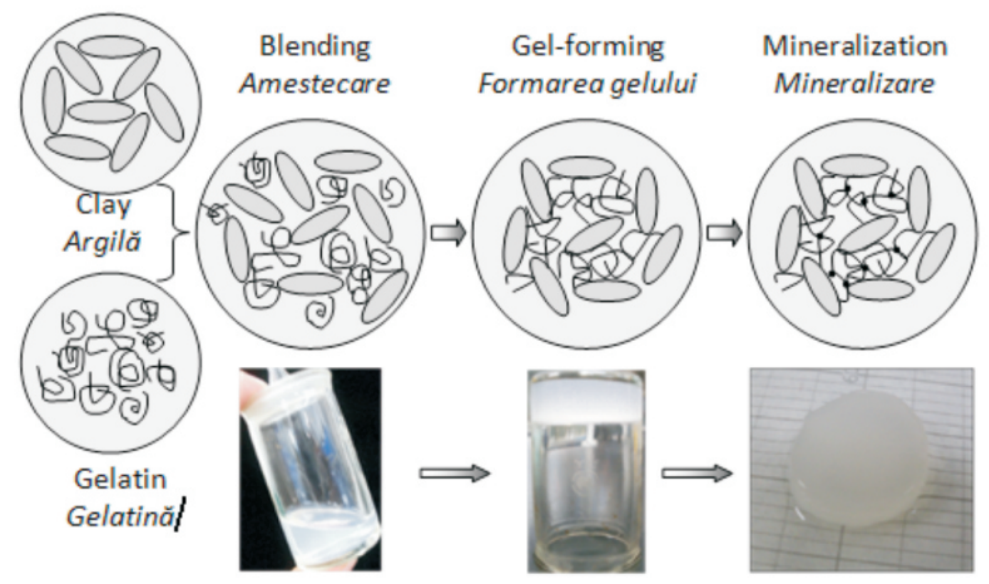

Figure 1. Schematic diagram for fabrication of gelatin-based hydrogels

Figura 1. Diagrama schematica pentru fabricarea hidrogelurilor pe baza de gelatina

As schematically illustrated in Figure 1, the preparation for gelatin-based hydrogels consisted of three procedures: blending, gel-forming and mineralization. The operations were as follows. Firstly $X$ $\mathrm{g}(\mathrm{X}=0.2,0.3,0.4$ and 0.5 , respectively) gelatin was dissolved in $5 \mathrm{ml}$ deionized water at $50^{\circ} \mathrm{C}$ for $2 \mathrm{~h}$ to get solution a, and $0.2 \mathrm{~g}$ clay was dispersed in another $5 \mathrm{ml}$ deionized water at $25^{\circ} \mathrm{C}$ with rapid agitation to get solution b. Next, the two solutions were blended with agitation, and the blends turned into a translucent sol after high-speed shear-stirring for about $5 \mathrm{~min}$. Thereafter, the composite sol was poured into a cylinder mold $(\Phi 3 \times 4 \mathrm{~cm})$ and then exposed to a cryogenic environment at $-20^{\circ} \mathrm{C}$ for $24 \mathrm{~h}$ to obtain hydrogels with physical cross-linking. Finally, the hydrogel was soaked in a $0.5 \mathrm{M} \mathrm{CaCl}_{2}$ solution for $48 \mathrm{~h}$, getting the final product.

\section{Characterization}

A SPM-9600 atomic force microscope (Shimadzu, Japan) was used to examine the microstructure change of the hydrogel at each procedure of fabrication. The IR spectra of lyophilized pure gelatin and final products were obtained on $\mathrm{KBr}$ pellet and performed on an MAGNA IR560 spectrophotometer (Nicolet, USA). The thermal stability of lyophilized pure gelatin and the hydrogel were assessed with DSC-60 (Shimadzu, Japan) over a temperature range of $30-200^{\circ} \mathrm{C}$. X-ray diffraction curves for clay and hydrogels were recorded at $2 \% \mathrm{~min}$ between $3^{\circ}$ and $55^{\circ}$ on a X'Pert Pro X-ray diffractometer
După cum ilustrează Figura 1, prepararea hidrogelurilor pe bază de gelatină a constat în trei proceduri: amestecare, formarea gelului şi mineralizare. Operaţiunile $s$-au desfăşurat astfel: mai întâi s-au dizolvat $X \mathrm{~g}(\mathrm{X}=0,2,0,3,0,4$, respectiv 0,5$)$ de gelatină în $5 \mathrm{ml}$ de apă deionizată la $50^{\circ} \mathrm{C}$ timp de $2 \mathrm{~h}$ pentru a obţine soluţia a, şi s-au dizolvat $0,2 \mathrm{~g}$ argilă în alte $5 \mathrm{ml}$ de apă deionizată la $25^{\circ} \mathrm{C} \mathrm{cu}$ agitare rapidă pentru a obţine soluţia $\mathrm{b}$. Apoi, cele două soluţii s-au amestecat prin agitare, şi s-au transformat în sol translucid după agitare la viteză mare timp de aproximativ $5 \mathrm{~min}$. După aceea, $\mathrm{s}$-a turnat solul compozit într-o formă cilindrică $(\Phi 3 \times 4 \mathrm{~cm})$ şi apoi a fost expus la un mediu criogenic la $-20^{\circ} \mathrm{C}$ timp de $24 \mathrm{~h}$ pentru a obţine hidrogeluri prin reticulare fizică. În cele din urmă, hidrogelul a fost înmuiat într-o soluţie de $0,5 \mathrm{M} \mathrm{CaCl}_{2}$ timp de $48 \mathrm{~h}$, obţinând astfel produsul final.

\section{Caracterizare}

S-a utilizat un microscop de forţă atomică A SPM9600 (Shimadzu, Japonia) pentru a examina modificările microstructurii hidrogelului în cadrul fiecărei proceduri de fabricare. Spectrele IR ale gelatinei pure liofilizate şi ale produselor finale au fost obţinute pe pastile de $\mathrm{KBr}$ şi au fost efectuate cu un spectrofotometru MAGNA IR560 (Nicolet, SUA). Stabilitatea termică a gelatinei pure liofilizate şi a hidrogelului a fost determinată cu aparatul DSC-60 (Shimadzu, Japonia) într-un interval de temperatură de $30-200^{\circ} \mathrm{C}$. S-au înregistrat curbele rezultate în urma difracţiei cu raze $X$ pentru argilă şi hidrogeluri la $2^{\circ} / \mathrm{min}$ 
(Philips, Netherlands) using CuK $\alpha$ radiation $(~ \gamma=0.154$ $\mathrm{nm}$ ) at a voltage of $40 \mathrm{kV}$ and a current of $35 \mathrm{~mA}$. The cross-sections in matrixes were observed with a JSM5900 scanning electron microscope (Philips, Netherlands) to get the microstructure of pores. Then an image analyzer program (Photoshop CS 8.0, Adobe) was used to obtain the top view of the voids in SEM images, in which at least 55 pores were measured to obtain the average diameter. The solvent replacement method was used for porosity measurements [3]. The sample was equilibrated in deionized water for $1 \mathrm{~h}$ and weighed before being maintained at $37^{\circ} \mathrm{C}$ and $40 \%$ relative humidity in an incubator (MJ-160B-Il, Shanghai). The water evaporation rate was measured by weighing the sample at consecutive intervals. The percentage weight remaining (WR) of composite was calculated by: între $3^{\circ}$ şi $55^{\circ} \mathrm{cu}$ un difractometru de raze $\mathrm{X}, \mathrm{X}^{\prime}$ Pert Pro (Philips, Olanda) utilizând radiaţia CuK $\alpha(\gamma=0,154 \mathrm{~nm})$ la un voltaj de $40 \mathrm{kV}$ şi un curent de $35 \mathrm{~mA}$. S-au observat secţiunile transversale ale matricelor cu un microscop electronic cu baleiaj JSM-5900 (Philips, Olanda) pentru a obţine microstructura porilor. Apoi s-a utilizat un program de analiză a imaginii (Photoshop CS 8.0, Adobe) pentru a obţine imagini SEM cu vedere de sus a porilor, în care s-au măsurat cel puţin 55 de pori pentru a obţine diametrul mediu. Pentru măsurarea porozităţii s-a utilizat metoda de înlocuire a solventului [3]. Proba s-a adus la echilibru în apă deionizată timp de $1 \mathrm{~h}$ şi s-a cântărit înainte, fiind menţinută la $37^{\circ} \mathrm{C}$ şi $40 \%$ umiditate relativă într-un incubator (MJ-160B-II, Shanghai). Gradul de evaporare a apei a fost măsurat prin cântărirea probei la intervale consecutive. Procentul de greutate rămasă (WR) a compozitului s-a calculat prin:

$$
\mathrm{WR}(\%)=\frac{\mathrm{Wr}}{\mathrm{Wi}} \times 100 \%
$$

where Wi is the initial weight of wet gels, and Wr is the weight of material at each interval time. unde Wi este greutatea iniţială a gelurilor umede, iar Wr este greutatea materialului în fiecare interval de timp.

\section{RESULTS AND DISCUSSION}

\section{REZULTATE ŞI DISCUTII}

\section{Fabrication Precision}
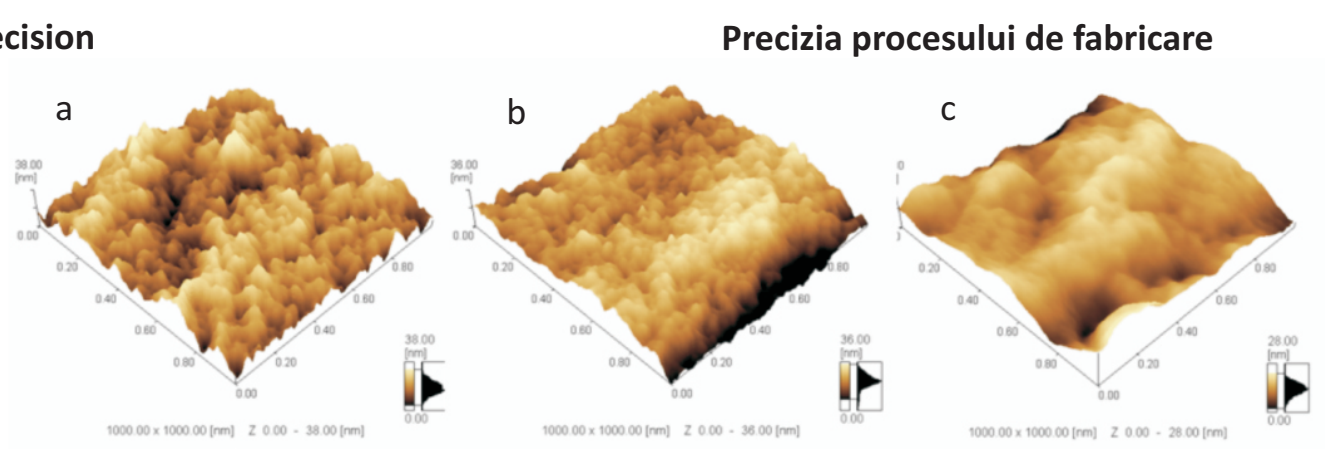

Figure 2. AFM images of the composites during the fabrication process

( $a, b$ and $c$ for the composites containing $2 \%$ gelatin and $2 \%$ clay at the end of each step)

Figura 2. Imagini AFM ale compozitelor în timpul procesului de fabricare

(a, b şi c pentru compozitele care conţin $2 \%$ gelatină şi $2 \%$ argilă la sfârşitul fiecărei etape)

The composite hydrogels were prepared with three procedures including blending, gel-forming and mineralization. The micro-morphology of the composite at the end of each step was observed by AFM and shown in Figure 2. During the blending, gelatin molecules combined with clay molecules to form multi-dispersed amorphous matter (Figure 2a).
S-au pregatit hidrogelurile compozite utilizând trei proceduri, si anume: amestecarea, formarea gelului si mineralizarea. Micro-morfologia compozitelor la finalul fiecarei etape a fost observata prin microscopie de forta atomica (AFM) si este prezentata în Figura 2. În timpul amestecarii, moleculele de gelatina s-au combinat $\mathrm{cu}$ moleculele de argila pentru a forma o materie amorfa 
While in the following two steps, the composite presented a more smoother and homogenous surface (Figure 2b, 2c), which suggested the gelatin molecules may interpenetrate into the interlayer region of clay molecules to obtain uniform composite.

The laponite clay has a layer structure, which, in dispersion in water, is in the form of disc-shaped crystals. The crystals become arranged into stacks which were held together electrostatically by sharing of sodium ions in the interlayer region between adjacent crystals. As indicated in Figure 3, although the $2 \theta$ had slight decrease from $28.35^{\circ}$ to $23.83^{\circ}$, the XRD curve for the final composite had similar pattern to that for the clay of non-crystal properties. These data demonstrated that the gelatin molecules did not destroy the platelets of the clay except increasing their distance by intercalating into the interlayer space and forming a heterogeneous network.

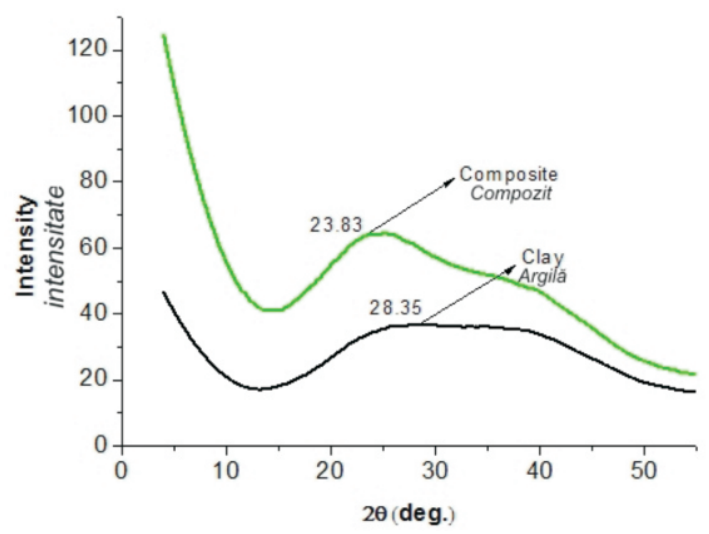

Figure 3. XRD patterns of clay and the composite (both gelatin and clay content as $2 \%$ )

Figura 3. Curbe XRD pentru argilă şi compozit (ambele conţin $2 \%$ gelatină şi argilă) multi-dispersa (Figura 2a). În urmatoarele doua etape, compozitul a prezentat o suprafata mai neteda si mai omogena (Figura 2b, 2c), ceea ce a sugerat ca moleculele de gelatina pot patrunde în regiunea stratului intermediar al moleculelor de argila pentru a obtine un compozit uniform.

Laponita are o structura stratificata, care, în dispersie apoasa, se prezinta ca niste cristale sub forma de disc. Cristalele se aranjeaza în straturi unite electrostatic prin intermediul ionilor de sodiu. Dupa cum indica Figura 3 , desi $2 \theta$ a scazut usor de la $28,35^{\circ}$ la $23,83^{\circ}$, curba XRD a compozitului final a avut o alură asemanatoare cu cea a argilei cu proprietati noncristaline. Aceste date au demonstrat ca moleculele de gelatina nu au distrus discurile de argila, ci doar au marit distanta dintre acestea prin intercalarea în spatiul stratului intermediar si formarii unei retele eterogene.

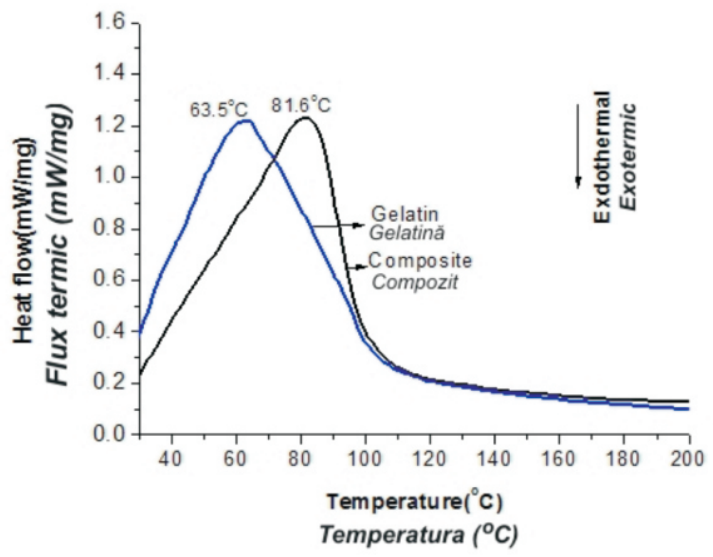

Figure 4. DSC thermographs of gelatin and the composite with $2 \%$ gelatin and $2 \%$ clay

Figura 4. Termograme DSC pentru gelatină şi compozit cu $2 \%$ gelatină şi $2 \%$ argilă

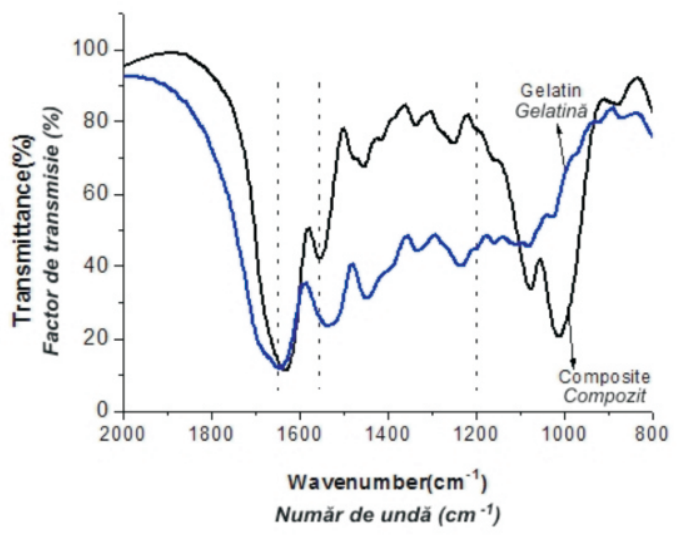

Figure 5. IR spectra of gelatin and the composite (both gelatin and clay content as $2 \%$ )

Figura 5. Spectre IR pentru gelatina si compozit (ambele contin $2 \%$ gelatina si argila) 
Figure 4 shows the DSC thermographs of the gelatin and hydrogel. The two curves were similar with only one endothermic peak associated to the helix-coil transition of gelatin, which was the denaturation temperature (Td). In theory, crosslinking degree increases the thermal stability of gelatin, as shown by the shift of the Td to higher values. In addition, it is generally accepted that the endothermic process present in the DSC thermogram of collagenous materials involves rupture of hydrogen bonds and a rearrangement of the triple helix into a random configuration. On the other hand, the increased thermal stability exhibited by gelatin, has been ascribed to the presence of crosslinking, which breaks exothermically. The $\mathrm{Td}$ of the composite rose by $18^{\circ} \mathrm{C}$ compared with the gelatin, which indicated that there was interaction between the gelatin and clay.

Gelatin is characterized by the amides of protein, IR spectra of which are located on two regions with amide I (anti-symmetric carboxylate absorbance or $\mathrm{C}=\mathrm{O}$ stretching vibration) and amide $\|$ bands ( $\mathrm{C}-\mathrm{N}$ stretching vibration or $\mathrm{N}-\mathrm{H}$ bending vibration). In this respect, the IR spectra for the hydrogel and gelatin were presented in Figure 5. Compared with gelatin, the amide peak of hydrogels hold a shift to higher wavenumber, to be specific, the spectra of $\delta\left(\mathrm{NH}_{2}\right)$ at 1537 and $1235 \mathrm{~cm}^{-1}$ disappeared while the spectra of $\delta\left(\mathrm{NH}_{3}{ }^{+}\right)$at 1553 and $1251 \mathrm{~cm}^{-1}$ emerged, indicating that the $-\mathrm{NH}_{2}$ in the gelatin was protonized in the fabrication process. Besides another significant change from 1645 to $1632 \mathrm{~cm}^{-1}$, attention was attracted by the $1460-1380$ $\mathrm{cm}^{-1}$ region, since certain differences can be seen in it: characteristic for the gelatin is at $1450 \mathrm{~cm}^{-1}$ with a shoulder at $1390 \mathrm{~cm}^{-1}$; for the hydrogel, a doublet at 1454 and $1417 \mathrm{~cm}^{-1}$ with a shoulder at $1473 \mathrm{~cm}^{-1}$. It is well known, in the spectral region considered, the bands of the deformation vibrations of $-\mathrm{C}-\mathrm{H}$ groups and the symmetrical stretching vibrations of $-\mathrm{C}-\mathrm{O}$ groups of ionized $-\mathrm{COO}$ groups appeared, the latter of which might be helpful for the formation of coordinate bonding. Otherwise, the characteristic absorption peaks of Si-O tetrahedron at $1013 \mathrm{~cm}^{-1}$ was found in the spectra of the composite, indicating the presence of silicate clay in the hydrogels.

As mentioned above, the formation of $-\mathrm{NH}_{3}^{+}$and $-\mathrm{COO}^{-}$was demonstrated by IR analyses. Also, the gelatin molecules interpenetrated into the interlayer region in the laponite clay forming a multiphase network. These results were available to elaborate the
Figura 4 prezintă termogramele DSC pentru gelatină şi hidrogel. Cele două curbe au fost asemănătoare cu un singur pic endotermic asociat tranziţiei helix-ghem a gelatinei, care a fost temperatura de denaturare (Td). Teoretic, gradul de reticulare creşte stabilitatea termică a gelatinei, aşa cum arată deplasarea Td spre valori mai mari. În plus, se acceptă în general că procesul endotermic prezent în termograma DSC a materialelor colagenice implică ruperea legăturilor de hidrogen şi rearanjarea triplului helix într-o configuraţie aleatorie. Pe de altă parte, stabilitatea termică crescută a gelatinei a fost atribuită prezenţei legăturilor încrucişate, care se rup exotermic. Td a compozitului a crescut cu $18^{\circ} \mathrm{C}$ în comparaţie cu cea a gelatinei, ceea ce a indicat că a existat o interacţiune între gelatină şi argilă.

Gelatina este caracterizată de amidele proteinei, ale cărei spectre IR sunt localizate în două regiuni cu benzile amidă I (absorbanţă carboxilat antisimetrică sau vibraţia de întindere $\mathrm{C}=0$ ) şi amidă II (vibraţia de întindere C-N sau vibraţia de îndoire N-H). În acest sens, spectrele IR pentru hidrogel şi gelatină sunt prezentate în Figura 5. În comparaţie cu gelatina, picurile amidă ale hidrogelurilor se deplasează spre numere de undă mai mari, mai exact, spectrele $\delta\left(\mathrm{NH}_{2}\right)$ de la 1537 şi $1235 \mathrm{~cm}^{-1}$ dispar, în timp ce apar spectrele $\delta\left(\mathrm{NH}_{3}{ }^{+}\right)$de la 1553 şi $1251 \mathrm{~cm}^{-1}$, indicând faptul că $-\mathrm{NH}_{2}$ din gelatină a fost protonizat în procesul de fabricare. În afară de o modificare semnificativă de la 1645 la $1632 \mathrm{~cm}^{-1}$, atenţia s-a îndreptat spre regiunea de la $1460-1380 \mathrm{~cm}^{-1}$, întrucât aici se pot observa anumite diferenţe: picul caracteristic pentru gelatină se situează la $1450 \mathrm{~cm}^{-1} \mathrm{cu}$ un umăr la $1390 \mathrm{~cm}^{-1}$; pentru hidrogel, un dublet la 1454 şi $1417 \mathrm{~cm}^{-1}$ cu un umăr la $1473 \mathrm{~cm}^{-1}$. Este binecunoscut faptul că, în regiunea spectrală luată în considerare, apar benzile de vibraţii de deformare ale grupărilor $-\mathrm{C}-\mathrm{H}$ şi vibraţiile de întindere simetrice ale grupărilor $-\mathrm{C}-\mathrm{O}$ ale grupărilor ionizate - $\mathrm{COO}$, cele din urmă putând ajuta la formarea legăturilor coordinative. Altfel, picurile de absorbţie caracteristice ale tetraedrului Si-O la $1013 \mathrm{~cm}^{-1}$ au fost găsite în spectrele compozitului, indicând prezenţa silicatului în hidrogeluri.

După cum am menţionat mai sus, formarea $-\mathrm{NH}_{3}^{+}$ şi $-\mathrm{COO}$ a fost demonstrată prin analize IR. De asemenea, moleculele de gelatină s-au întrepătruns în regiunea stratului intermediar al laponitei formând o reţea multifazică. S-au utilizat aceste rezultate pentru elaborarea procesului de fabricare a hidrogelurilor pe 
fabrication process of the gelatin-based hydrogels. The laponite clay consists of the platelets tightly bound together, which might be exfoliated and dispersed homogenously in a solution by absorbing water into interlayer region. In this study, the clay was firstly dispersed in water with rapid agitation, the interlayer surface of which had a negative charge. After high shear blending, the gelatin in the mixture $(\mathrm{pH}=8.5$, higher than that of the gelatin) also had a negative charge, resulting in a polydispersed composite at the end of the first procedure, "blending". Because of small localized positive charges at the edges of the interlayer of the clay generated by absorption of hydroxyl groups, gelatin could interpenetrate into the interlayer region by electrostatic forces in the following cryogenic processing. In the final calcium mineralization step, some $-\mathrm{NH}_{2}$ groups in the gelatin turned into $-\mathrm{NH}_{3}^{+}$in the presence of calcium chloride, imparting gelatin partial cationic charge, which may be helpful for the electrostatic bonding between the platelets of the clay and the gelatin. Otherwise, calcium ion may suppress the electric double layer surrounding the platelets of the clay and cause the flocculation of the clay, which leads to the strengthened interactions between the clay and the gelatin by shortening their distance. Furthermore, calcium ion could form coordinate or ionic linkage between gelatin and gelatin, as well as gelatin and clay, which ultimately intensified the crosslinking and stability of the whole system. bază de gelatină. Laponita constă din discuri legate strâns, care se pot exfolia şi dispersa omogen într-o soluţie prin absorbţia de apă în regiunea stratului intermediar. În acest studiu, argila a fost mai întâi dispersată în apă prin agitare rapidă, suprafaţa stratului intermediar având o sarcină negativă. După amestecare cu forţă de forfecare mare, gelatina din amestec ( $\mathrm{pH}=8,5$, mai mare decât cel al gelatinei) a avut o sarcină negativă, având ca rezultat un compozit polidispers la finalul primei proceduri de „amestecare”. Din cauza sarcinilor pozitive mici localizate la marginile stratului intermediar al argilei, generate de absorbţia grupelor hidroxil, gelatina a putut întrepătrunde în regiunea stratului intermediar prin forţele electrostatice la prelucrarea criogenică ulterioară. În etapa finală de mineralizare cu calciu, unele grupări $-\mathrm{NH}_{2}$ din gelatină s-au transformat în $-\mathrm{NH}_{3}{ }^{+}$în prezenţa clorurii de calciu, conferind gelatinei o încărcare cationică parţială, care ar putea fi utilă pentru formarea de legături electrostatice între discurile de argilă şi gelatină. În caz contrar, ionul de calciu poate suprima stratul electric dublu din jurul discurilor din argilă şi poate provoca flocularea argilei, ceea ce duce la interacţiuni consolidate între argilă şi gelatină prin scurtarea distanţei dintre acestea. În plus, ionul de calciu poate forma legături coordinative sau ionice între gelatină şi gelatină, precum şi între gelatină şi argilă, ceea ce a intensificat, în cele din urmă, reticularea şi stabilitatea întregului sistem.

\section{Effect of the Gelatin Content on the Micro- morphology}

Influenţa conţinutului de gelatină asupra micromorfologiei
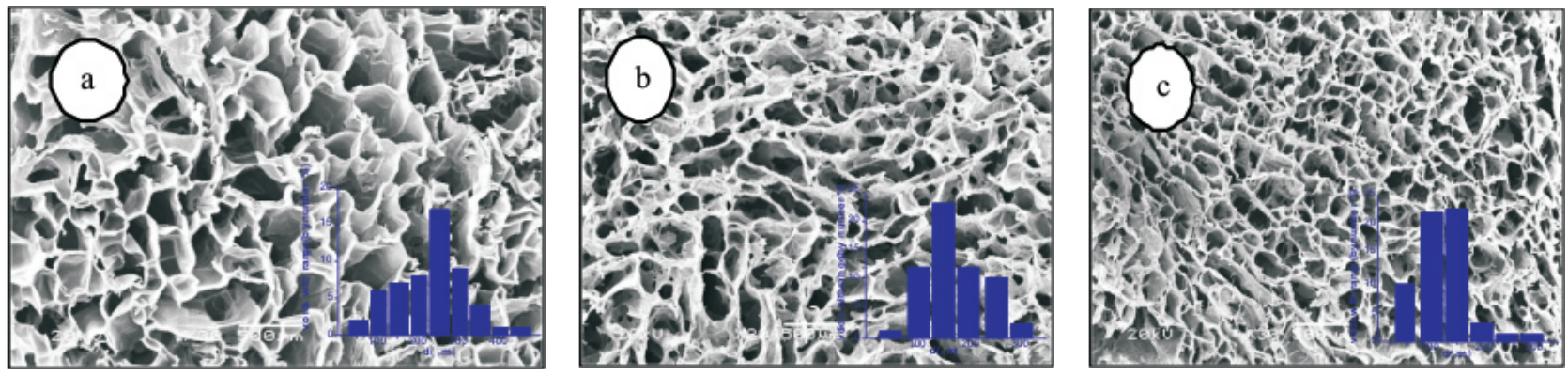

Figure 6. SEM images of the porous hydrogels

(gelatin content as a, $3 \% ; \mathrm{b}, 4 \% ; \mathrm{c}, 5 \%$; clay content as $2 \%$ )

Figura 6. Imagini SEM ale hidrogelurilor poroase

(continutul de gelatina: a - 3\%, b - 4\%, c - 5\%; continutul de argila 2\%)

Three types of hydrogels with different gelatin content were prepared and their SEM images and the
S-au pregătit trei tipuri de hidrogeluri cu conţinut diferit de gelatină, iar imaginile lor SEM şi distribuţia 
pore size distribution were displayed in Figure 6. The average pore diameter was calculated and shown in Table 1. As indicated, both the porosity and the pore size decreased with an increasing content of gelatin in the hydrogels. There are two possible explanations for the observed findings. First, a higher gelatin concentration could result in an increasing growth rate of nucleation in the composites of gelatin and silicate and thus in a higher amount of pores. Nucleation depends on the instability of the liquor phase as well as the diffusion of atoms into clusters, the former increases with decreasing of temperature, and the latter increases with increasing of temperature. Higher gelatin content resulted in a decrease of the freezing temperature of the solvent. As a result, the mobility of the atoms to diffuse into clusters was higher, and the nucleation rate increased. Second, by comparison of the gelatin content, the more concentrated materials could possess a decreased heat and protein transfer and thus result in smaller pores. A combination of both is likely the most plausible explanation. mărimii porilor sunt prezentate în Figura 6. S-a calculat diametrul mediu al porilor, care este prezentat în Tabelul 1. După cum s-a indicat, atât porozitatea, cât şi mărimea porilor au scăzut la un conţinut mare de gelatină în hidrogeluri. Există două explicaţii posibile pentru constatările observate. În primul rând, o concentraţie mai mare de gelatină ar putea conduce la o rată de creştere tot mai mare a nucleaţiei în compozitele de gelatină şi silicat şi, astfel, la o cantitate mai mare de pori. Nucleaţia depinde de instabilitatea fazei lichide, precum şi de difuzia atomilor în grupuri; prima creşte odată cu scăderea temperaturii, iar cea din urmă creşte odată cu creşterea temperaturii. Conţinutul mai mare de gelatină a dus la o scădere a temperaturii de congelare a solventului. Ca urmare, mobilitatea atomilor de a difuza în grupuri a fost mai mare, iar rata de nucleaţie a crescut. În al doilea rând, prin compararea conţinutului de gelatină, materialele mai concentrate ar putea deţine un transfer de căldură şi de proteine scăzut şi, astfel, rezultă pori mai mici. Cea mai plauzibilă explicaţie este probabil o combinaţie a celor două.

Table 1: The morphological properties of porous gelatin-based hydrogels Tabelul 1: Proprietăţile morfologice ale hidrogelurilor poroase pe bază de gelatină

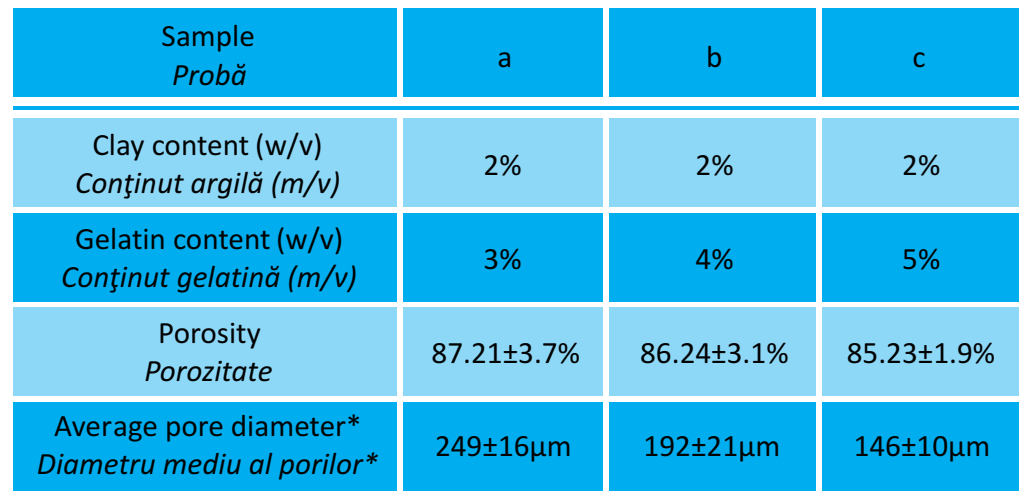

*At least 55 pores were assessed and the values were statistically analyzed and also expressed as the mean \pm standard deviation.

*S-au evaluat cel puţin 55 de pori, iar valorile au fost analizate statistic şi exprimate ca \pm abatere standard medie.

Figure 6 also demonstrated the morphology of the pores in the gelatin-based hydrogels. The pores were interconnecting in the four hydrogels, and their average size decreased with the rising gelatin content in the gels. Furthermore, in this material containing 5\% gelatin, the pore volume ranged from $50-350 \mu \mathrm{m}$, focusing on a range of 100-200 $\mu \mathrm{m}$. Such pore size and matrix structure are coincidentally preferred by biomaterials [4], since gradient through this kind of matrix can help oxygen and nutrients diffuse to the cells, and waste products to drain out of the matrix,
Figura 6 a demonstrat, de asemenea, morfologia porilor în hidrogelurile pe bază de gelatină. Porii s-au interconectat în cele patru hidrogeluri, iar dimensiunea medie a acestora a scăzut odată cu creşterea conţinutului de gelatină din gel. În plus, în acest material care conţine $5 \%$ gelatină, volumul porilor a variat între $50-350 \mu \mathrm{m}, \mathrm{cu}$ accentul pe intervalul 100-200 $\mu \mathrm{m}$. Astfel de dimensiuni ale porilor şi structură a matricei sunt întâmplător preferate de biomateriale [4], deoarece gradientul prin acest tip de matrice poate ajuta oxigenul şi substanţele nutritive să difuzeze în celule şi deşeurile să se scurgă 
whereas the pore interconnectivity can promote cell migration and angiogenesis.

\section{Effect of the Gelatin Content on the Solvent Evaporation Rate}

The weight of the hydrogels was determined at different time intervals when exposed to a condition of $37^{\circ} \mathrm{C}$ and $40 \%$ relative humidity. The weight of the material decreased linearly in the initial $2.5 \mathrm{~h}$, while gently lowered with the prolonged time (Figure 7). Additionally, the evaporation rate of water slowed with the rising gelatin content. The total volume of the liquid absorbed by gel consists of the solvating solvent bound to polymer network and the capillary solvent filling macropores which can evaporate easier. There was more water absorbed in the large amount of microscopic subunits in the hydrogel with $5 \%$ gelatin, resulting in the slowest water evaporation. In addition, the water content in such matrix could be retained higher than $75 \%$ even if after $24 \mathrm{~h}$ in this case. It is reported that a commercially available dressing loses about $50 \%$ of its bound water after $12 \mathrm{~h}$ and retains about 30\% water after $24 \mathrm{~h}$. Therefore the gelatinbased hydrogels could be considered as a potential wound dressing because they could provide a fine moist environment for healing wound surface [5]. afară din matrice, iar interconectivitatea porilor poate promova migrarea celulelor şi angiogeneza.

\section{Influenţa conţinutului de gelatină asupra gradului de evaporare a solventului}

Greutatea hidrogelurilor s-a determinat la diferite intervale de timp când acestea au fost expuse la o temperatură de $37^{\circ} \mathrm{C}$ şi umiditate relativă de $40 \%$. Greutatea materialului a scăzut liniar în primele $2,5 \mathrm{~h}$, şi a scăzut uşor în timp (Figura 7). În plus, gradul de evaporare a apei s-a micşorat odată cu creşterea conţinutului de gelatină. Volumul total al lichidului absorbit de gel constă din solventul de dizolvare legat la reţeaua polimerică şi solventul capilar ce umple macroporii care se pot evapora uşor. S-a absorbit mai multă apă în cantitatea mare de subunităţi microscopice din hidrogelul cu 5\% gelatină, având ca rezultat cea mai lentă evaporare a apei. În plus, conţinutul de apă într-o astfel de matrice poate fi menţinut peste $75 \%$, chiar şi după $24 \mathrm{~h}$ în acest caz. S-a raportat că un pansament disponibil în comerţ pierde circa $50 \%$ din apa legată după 12 h şi reţine circa $30 \%$ apă după 24 de ore. Prin urmare, hidrogelurile pe bază de gelatină pot fi considerate un potenţial pansament pentru răni, deoarece pot oferi un mediu umed pentru vindecarea rănilor de suprafaţă [5].

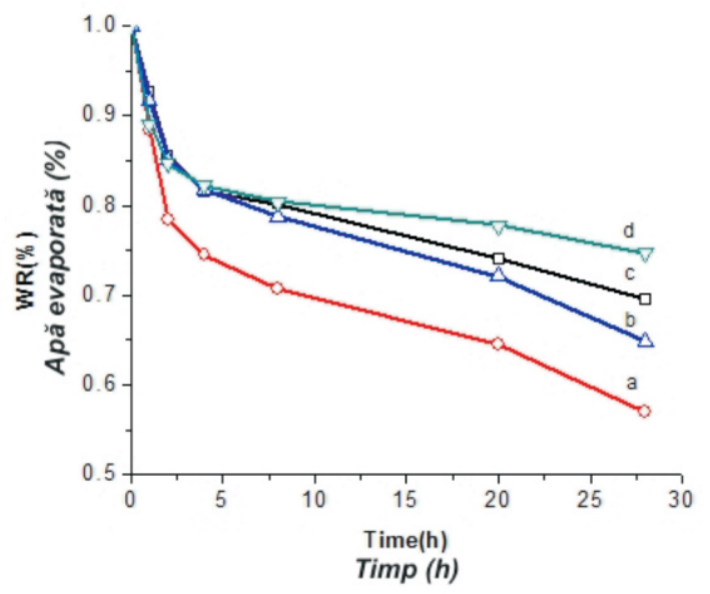

Figure 7. Evaporative water losses from the hydrogels

(gelatin content as a, $2 \% ; b, 3 \% ; c, 4 \%$;, $5 \%$; clay content as $2 \%$ )

Figura 7. Apa evaporată din hidrogeluri

(conţinut gelatină: a - 2\%, b-3\%, c - 4\%, d - 5\%; conţinut argilă 2\%) 


\section{CONCLUSIONS}

An aqueous system was proposed and confirmed for preparing porous hydrogels with gelatin and laponite clay. The fabrication was identified as blending, gel-forming and mineralization three steps. The pore morphology, the pore size and the water evaporation rate could be easily controlled by varying the gelatin content. The hydrogel, consisting of $5 \%$ gelatin and $2 \%$ clay, had interconnecting pores with size focusing on a range of $100-200 \mu \mathrm{m}$, which would be available as scaffolds and wound dressings. This approach offers the advantage of fabricating the hierarchical organization of organic/inorganic components without using organic solvents and could be extended to develop new porous materials for a wide range of technological applications.

\section{Acknowledgements}

The authors wish to thank the Ministry of Science and Technology of China for financial support of the cooperation project (No.2009DFA42850 and No. 40-3).

\section{CONCLUZII}

S-a propus şi confirmat un sistem apos pentru pregătirea unor hidrogeluri poroase cu gelatină şi argilă de tip laponită. Procesul de fabricare s-a desfăşurat în trei etape: amestecare, formarea gelului şi mineralizare. Morfologia porilor, dimensiunea porilor şi gradul de evaporare a apei pot fi controlate cu uşurinţă prin variaţia conţinutului de gelatină. Hidrogelul, constând din $5 \%$ gelatină şi $2 \%$ argilă, are porii interconectaţi cu dimensiuni în intervalul 100-200 $\mu \mathrm{m}$ şi poate fi realizat sub formă de suport şi pansament. Această abordare oferă avantajul fabricării componentelor organice/anorganice organizate ierarhic fără a utiliza solvenţi organici şi s-ar putea extinde în vederea dezvoltării unor noi materiale poroase pentru o gamă largă de aplicaţii tehnologice.

\section{Mulţumiri}

Autorii doresc să mulţumească Ministerului Ştiinţei şi Tehnologiei din China pentru susţinerea financiară a proiectului de cooperare (nr. 2009DFA42850 şi nr. 40-3).

\section{REFERENCES}

1. Barbetta, A. et al., "Porous gelatin hydrogels by gas-in-liquid foam templating", Soft Matter, 2010, 6, 8, 1785-1792.

2. Bigi, A. et al., "Relationship between triple helix content and mechanical properties of gelatin films", Biomaterials, 2004, 25, 25, 5675-5680.

3. Lai, J.Y., Li, Y.T., "Functional assessment of cross-linked porous gelatin hydrogels for bioengineered cell sheet carriers", Biomacromolecules, 2010, 11, 5, 1387-1397.

4. Vlierberghe, S.V. et al., "Porous gelatin hydrogels: 1. Cryogenic formation and structure analysis", Biomacromolecules, 2007, 8, 2, 331-337.

5. Mu, C.D. et al., "Collagen cryogel cross-linked by dialdehyde starch”, Macromol. Mater. Eng., 2010, 295, 2, $100-107$. 